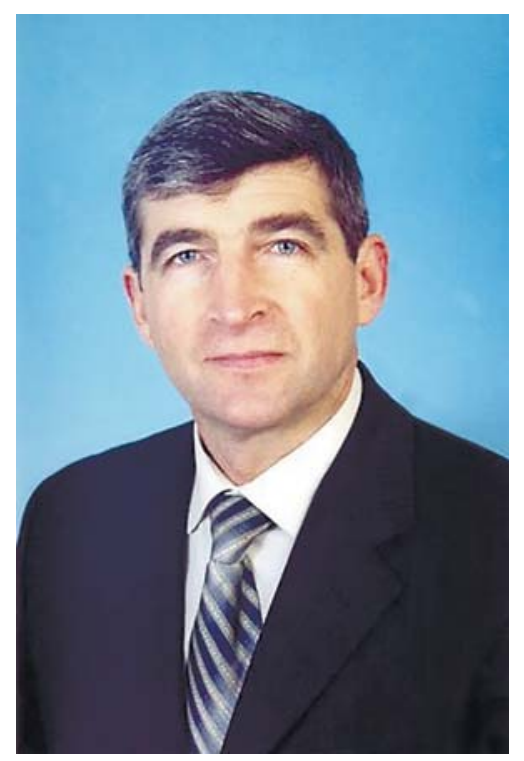

БАХМУТОВ

Володимир Георгійович доктор геологічних наук, завідувач відділу петромагнетизму і морської геофізики Інституту геофізики ім. C.I. Субботіна НАН України

\section{ПРО РЕЗУЛЬТАТИ НАУКОВИХ ДОСЛІДЖЕНЬ УКРАЇНСЬКИХ УЧЕНИХ В АНТАРКТИЦ}

\section{Стенограма наукової доповіді на засіданні Президії НАН України 17 березня 2021 року}

Доповідь приурочено до 25-ї річниці заснування української антарктичної станиіі «Академік Вернадський». Розглянуто історію розвитку антарктичних досліджень в Україні. Підкреслено, що фахівиі Начіональної академї наук України відігравали і відіграють провідну роль у започаткуванні та виконанні різнопланових наукових досліджень на станцї «Академік Вернадський». Наведено найвагоміші результати, отримані вченими установ НАН України в рамках їх участі у виконанні Державної цільової науково-технічної програми проведення досліджень в Антарктиці на 2011-2023 роки.

Шановний Анатолію Глібовичу!

Шановні члени Президії!

Мою доповідь присвячено участі Національної академії наук України у виконанні Державної цільової науково-технічної програми проведення досліджень в Антарктиці. Крім того, цього року виповнилося 25 років відтоді, як Велика Британія остаточно передала Україні свою антарктичну станцію. Цю дату, 6 лютого 1996 р., коли на станції відбулася церемонія підняття українського прапора, офіційно прийнято вважати початком діяльності України на шостому континенті. Слід особливо підкреслити, що ключова роль у становленні України як антарктичної держави належала Національній академії наук.

Коротко нагадаю основні події, пов'язані з історією української антарктичної станції «Академік Вернадський», та окремо зупинюся на внеску деяких установ НАН України в розвиток досліджень Антарктики.

Досить часто в мас-медійному просторі лунає запитання: «А навіщо Україні потрібна Антарктида?». Річ у тім, що сьогодні практично жодну науково-природничу проблему глобального характеру неможливо вирішити без урахування явищ і процесів в Антарктиці. Цей континент займає близько $10 \%$ 
поверхні Землі. Антарктика - це 70 \% світових запасів прісної води. У Приантарктичних морях зосереджені величезні рибні ресурси, континент та його шельфова частина багаті на корисні копалини, зокрема мінеральні і вуглеводневі. Зараз на розробку родовищ накладено тимчасову заборону, але вже в недалекому майбутньому доступ до ресурсів Антарктики здійснюватиметься насамперед зважаючи на присутність тієї чи іншої країни в регіоні та 3 урахуванням іï внеску у вивчення льодового континенту. До того ж Антарктида - це унікальна природна лабораторія, де вчені шукають відповіді на актуальні питання сьогодення, пов'язані з проблемами глобального потепління, космічної погоди, озонової діри тощо. Тому участь у наукових дослідженнях в Антарктиці на базі власної наукової антарктичної станції $є$ одним з пріоритетів будь-якої держави і має не лише наукове, а й стратегічне та геополітичне значення.

Відповідно до Договору про Антарктику, підписаного в 1959 р., шостий континент є без'ядерною демілітаризованою зоною, вільною і доступною для наукових досліджень. Цей договір відкрив широкі перспективи для безпрецедентного міжнародного співробітництва.

Ще за часів Радянського Союзу, з кінця 1950-х і до початку 1990-х років, українські вчені та інженери брали активну участь в освоєнні Антарктики у складі радянських експедицій. Зі здобуттям Україною незалежності почалося її становлення як антарктичної держави.

У вересні 1992 р. Україна приєдналася до Договору про Антарктику, а вже за рік на базі Національної академії наук було засновано Український антарктичний центр, який очолив директор Інституту геологічних наук НАН України академік НАН України Петро Феодосійович Гожик. Водночас було створено міжвідомчий Антарктичний комітет під керівництвом директора Інституту геофізики ім. C.I. Субботіна НАН України академіка НАН України Віталія Івановича Старостенка.

$\mathrm{У}$ той самий час Велика Британія приймає рішення про закриття своєї антарктичної станції «Фарадей», а згодом - про передачу їі Україні. Ця майже неймовірна історія детально і яскраво описана у нещодавно випущеній книжці «Моя Антарктика» [1] директора Інституту біохімії ім. О.В. Палладіна НАН України академіка НАН України Сергія Васильовича Комісаренка, який тоді був послом України у Великій Британії. Завдяки зусиллям С.В. Комісаренка, тодішнього президента НАН України Б.Є. Патона та багатьох інших науковців і ентузіастів, а також за підтримки уряду Україні пощастило отримати власну антарктичну станцію.

У цей період, крім Києва, було створено й регіональні антарктичні центри НАН України в Одесі та Львові. Українські вчені зосередилися на розвитку нових напрямів досліджень, окреслених першою Державною програмою досліджень в Антарктиці на 2002-2010 роки.

Ця програма здобула міжнародне визнання, і в 2004 р. Україна отримала статус консультативної сторони Договору про Антарктику. Для довідки: зі 193 країн, які входять до Організації Об'єднаних Націй, тільки 29 мають цей, найвищий, статус.

Потім було прийнято Державну цільову науково-технічну програму проведення досліджень в Антарктиці на 2011-2023 роки.

Метою Програми досліджень в Антарктиці є проведення фундаментальних і прикладних наукових досліджень, забезпечення ефективного функціонування станції «Академік Вернадський», виконання міжнародних зобов'язань відповідно до Договору про Антарктику і проведення науково обгрунтованої оцінки біологічного та мінерально-ресурсного потенціалу регіону.

Програмою передбачено проведення комплексних досліджень, які підтримуються міжнародним Науковим комітетом 3 антарктичних досліджень (SCAR), за такими основними науковими напрямами: геолого-геофізичні, гідрометеорологічні, океанографічні, геокосмічні, біологічні, медико-фізіологічні дослідження, розроблення і впровадження нових технологій. Окремо слід відзначити роботу 3 організації і проведення експедицій, співпра- 


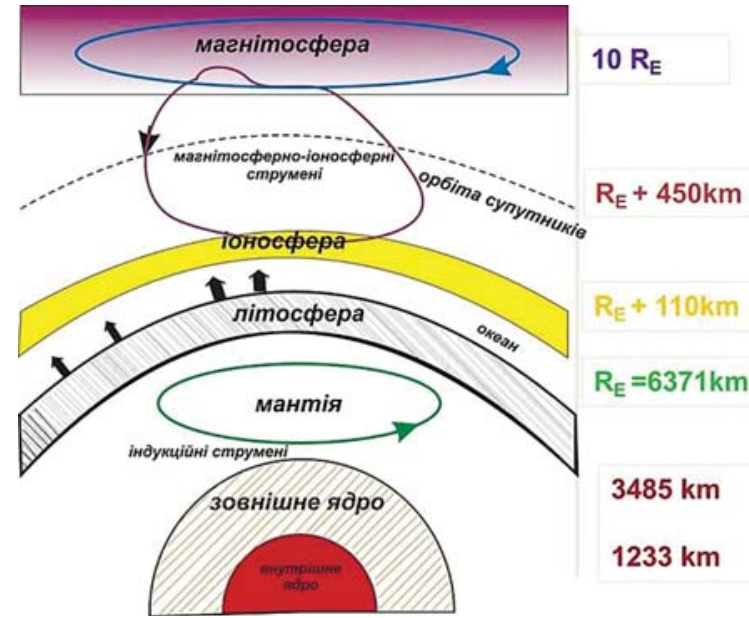

Puc. 1. Комплексне вивчення еволюції різних геосфер Землі (від земного ядра до близького космосу) дозволяє отримувати нові знання про процеси, які в них відбуваються

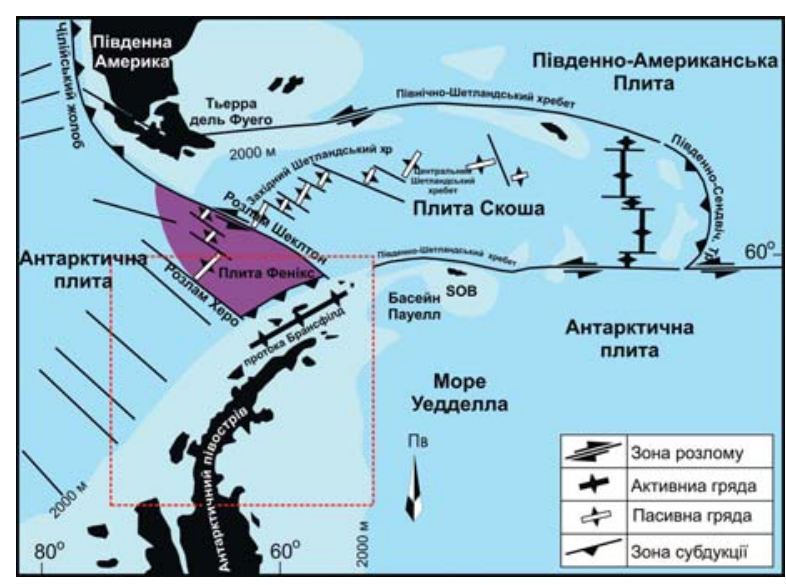

Puc. 2. Основні тектонічні структури Антарктичного півострова і моря Скоша [5]. Прямокутником позначено район досліджень

цю 3 міжнародними організаціями в рамках Договору про Антарктику та інформаційновидавничу діяльність.

Виконання завдань Програми забезпечується проведенням неперервних моніторингових спостережень; сезонних експедиційних робіт; обробки і аналізу даних дистанційних методів зондування; наукових досліджень у провідних академічних установах і університетських закладах.
Моніторингові спостереження виконують під час зимівлі. Слід зазначити, що безперервні ряди метеорологічних, магнітометричних, озонометричних та інших спостережних даних накопичено ще з 50-х років минулого століття. Це найтриваліші спостереження в Антарктиці, і цінність такого наукового матеріалу для дослідження довгострокових змін різних геофізичних параметрів важко переоцінити.

На сьогодні станція «Академік Вернадський» - це унікальний науково-дослідницький комплекс, який включає геомагнітну обсерваторію, апаратуру для досліджень геокосмосу, сейсмоакустичного моніторингу, гідрометеорологічних та океанографічних спостережень, лабораторії для проведення біологічних та медико-фізіологічних досліджень. Станція є опорним пунктом світової мережі Всесвітньої метеорологічної організації для спостережень за кліматом та світової мережі INTERMAGNET для спостереження за станом геомагнітного поля та космічної погоди.

Під час сезонних експедиційних робіт виконують дослідження в районі станції, на прилеглих островах та на материковій частині Антарктичного півострова, а також дослідження під час морських рейсів на акваторіях протоки Дрейка, моря Скоша і моря Беллінсгаузена. Якщо проаналізувати результати чотирьох українських морських антарктичних експедицій наприкінці 90-х - на початку 2000-х років, можна впевнено зробити висновок про високу ефективність за всіма напрямами досліджень - біологічних, геолого-геофізичних, океанографічних тощо.

До наукових досліджень в Антарктиці залучено потенціал провідних лабораторій академічних установ та закладів вищої освіти в рамках науково-технічних проєктів з використанням первинних даних, зразків та матеріалів, отриманих під час антарктичних експедицій. Загалом участь у зимівлях на станції «Академік Вернадський», у морських і сезонних експедиціях брали фахівці з 36 установ НАН України.

Серед основних наукових напрямів Державної програми можна виокремити дослідження

ISSN 1027-3239. Visn. Nac. Acad. Nauk Ukr. 2021. (4) 
в галузі наук про Землю [2-4]. Фахівці з геології, геофізики, геодезії, радіофізики з різних академічних інститутів проводять комплексне вивчення різних геосфер Землі. Їхніми зусиллями на станції створено сучасну геофізичну обсерваторію, що дає змогу досліджувати процеси в різних оболонках Землі: від ядра до геокосмосу (рис. 1).

Отримання нових знань про еволюцію геосфер неможливе без розуміння ї взаємодії та процесів, які в них відбуваються. Ці процеси мають різну природу, зумовлені різними фізичними механізмами, характеризуються різною енергетикою і охоплюють різні часові діапазони - від секунд до мільйонів років. Символічно, що станцію названо на честь видатного українського вченого-енциклопедиста Володимира Івановича Вернадського, оскільки саме він синтезував загальне уявлення про світ, його сутність у цілому та зв'язок явищ у всіх земних оболонках.

Із застосуванням новітніх методик і технологій геофізичних досліджень виявлено фундаментальні закономірності глибинної будови земної кори і літосфери Західної Антарктики. В Інституті геофізики ім. C.I. Субботіна НАН України на основі комп'ютерного моделювання було встановлено зв'язки між хвильовим, гравітаційним і магнітним полями, побудовано комплексні моделі глибинної будови блоку Антарктичного півострова та показано його геодинамічну еволюцію при деструкції суперконтиненту Гондвана (рис. 2, 3). Ці дані є базовим матеріалом для визначення ділянок, перспективних на родовища рудних і нерудних корисних копалин.

Просторово-часові зв’язки глибинної будови літосфери і тектонічної еволюції Антарктики було визначено також за допомогою моделювання даних супутникової альтиметрії. В Інституті геологічних наук НАН України розроблено метод «гравітаційної томографії», який дозволяє виділяти тектонічні структури в різних шарах Землі. Результати представлено в Атласі глибинної будови Антарктики за даними методу гравітаційної томографії, виданому англійською мовою (рис. 4).
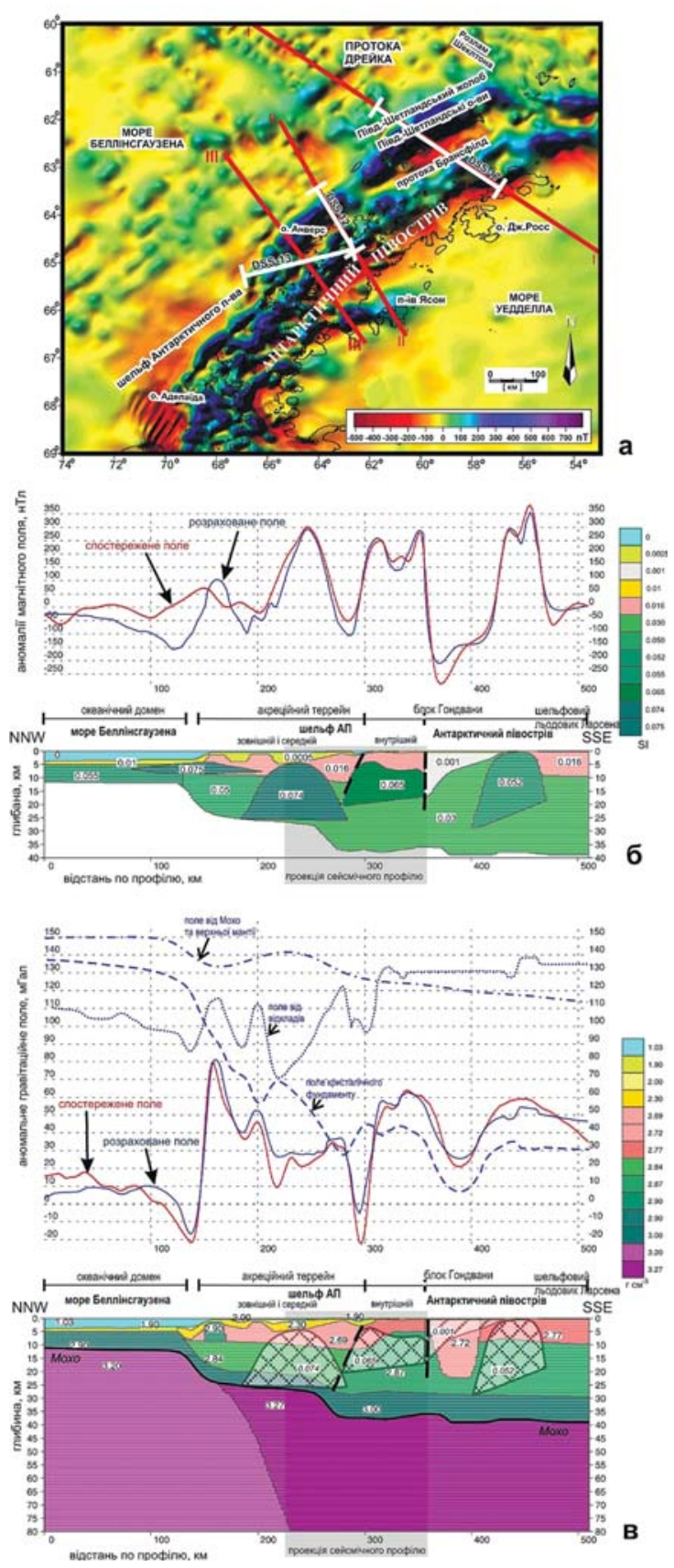

Puc. 3. Аномальне магнітне поле $\Delta T$ за даними аеромагнітних зйомок блоку Антарктичного півострова [6], розташування сейсмічних профілів ГСЗ та профілів моделювання показано, відповідно, білими і червоними лініями ( $a$ ); магнітна модель (б) і густинна модель (в) кори і верхньої мантії вздовж профілю III-ІІІ [7]: виділені магнітні тіла 3 розрахованою магнітною сприйнятливістю в од. SI, густину різних шарів наведено в г $/ \mathrm{cm}^{3}$ 

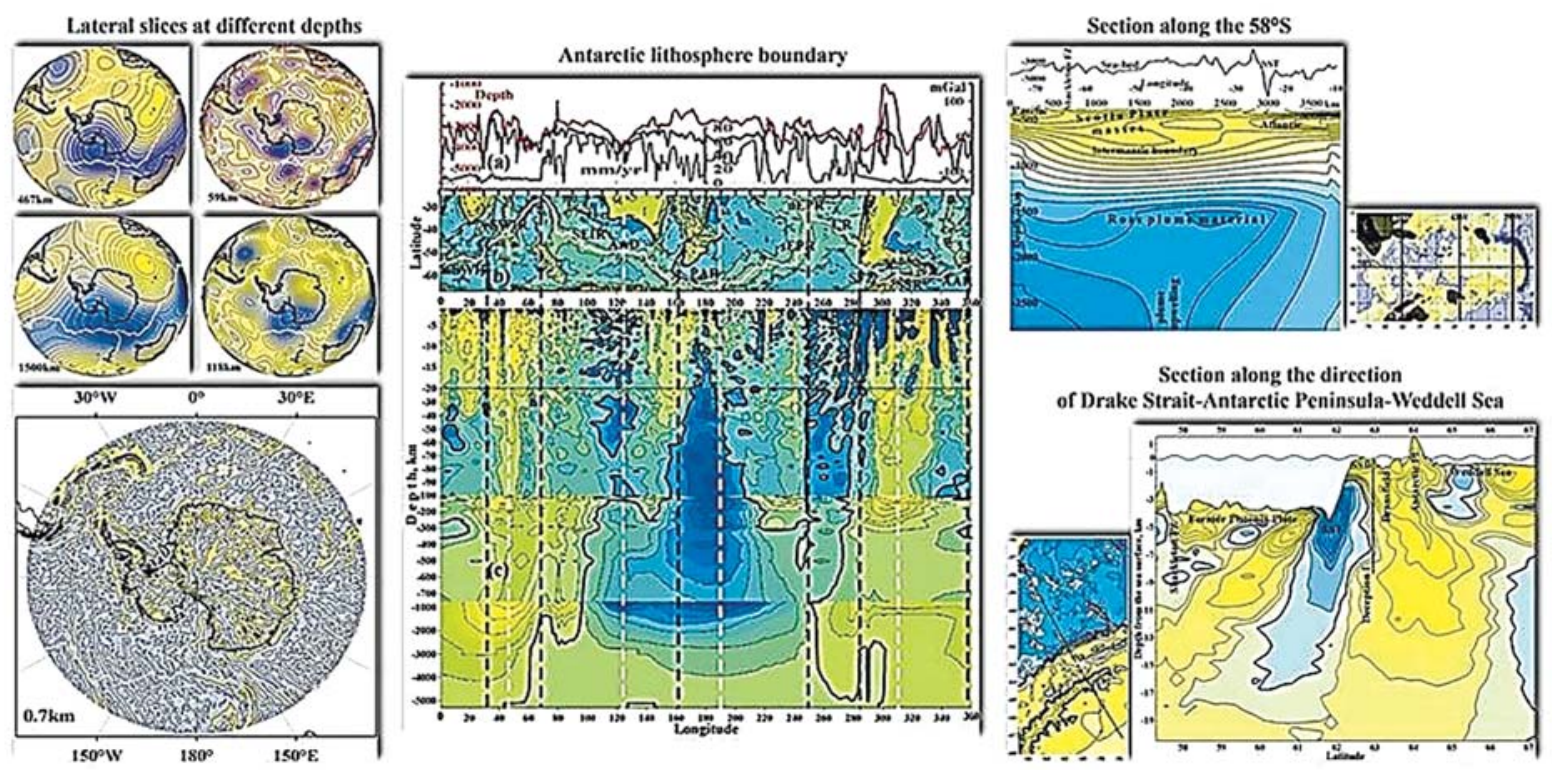

Puc. 4. Атлас глибинної будови Антарктики за даними методу гравітаційної томографії [8]

3 огляду на особливу роль Антарктичного півострова у геологічній історії всієї Антарктики для дослідження сучасних геодинамічних процесів на базі станції «Академік Вернадський» створено тектономагнітний, геодинамічний і гляціологічний полігони, на яких отримано на сьогодні вже майже 20-річні ряди моніторингових спостережень. Про ці дослідження більш детально доповість Валентин Юхимович Максимчук.

Антарктида - унікальний полігон для досліджень як динаміки кріосфери, так і довгострокових кліматичних змін. Антарктичний півострів є одним 3 регіонів найінтенсивнішого потепління на планеті, де середньорічна температура за останні 60 років підвищилася на $2,5^{\circ} \mathrm{C}$, що призводить до інтенсивного танення льодовиків (рис 5). Вивчення процесів, унаслідок яких відбуваються такі катастрофічні зміни, є одним з пріоритетних напрямів Державної програми проведення досліджень в Антарктиці (рис. 6).

Базовим матеріалом для цього, крім метеорологічних даних, є інформація про динаміку острівних і вивідних материкових льодовиків, для чого було використано розробки в галузі супутникової планетарної геодезії - супут- никову всепогодну радіолокацію та методи цифрової фотограмметрії. Острівні льодовики є дуже чутливими індикаторами довгострокових кліматичних змін. Три роки тому було започатковано георадарні дослідження і буріння з відбором льодового керну.

Зусиллями вчених Українського гідрометеорологічного інституту ДСНС України та НАН України досягнуто значного прогресу в реконструюванні атмосферної циркуляції Південної півкулі, що дає змогу прогнозувати зміни погодних умов у Західній Антарктиці та в районі станції «Академік Вернадський». За участю науковців Інституту проблем математичних машин та систем НАН України створено нову термогідродинамічну модель формування льодового покриву антарктичних морів.

Наступними шарами є верхня атмосфера, іоносфера і магнітосфера. Район станції є унікальним для експериментальних досліджень впливу нейтральної атмосфери на стан геокосмічної плазми, оскільки тут поєднуються низький рівень електромагнітних завад, значні відмінності географічних і геомагнітних широт, висока циклонічна активність, спокійні фонові умови іоносфери, наявність геомагнітної аномалії, а також озонової діри [2, 4].

ISSN 1027-3239. Visn. Nac. Acad. Nauk Ukr. 2021. (4) 
За допомогою унікальної апаратури, розробленої вченими Львівського центру Інституту космічних досліджень НАН України і ДКА України, на станції створено електромагнітний полігон, який не має аналогів у світі. Науковці Радіоастрономічного інституту НАН України вперше провели систематичні комплексні дослідження взаємодії атмосферної та космічної погодних систем, розробили адекватну фізичну модель перенесення приповерхневих збурень на висоти геокосмосу. Вперше було введено поняття «електромагнітний клімат» Землі і започатковано його систематичні спостереження у низькочастотній смузі варіацій напруженості природних електромагнітних полів трьох шарів навколоземного простору 3 різною густиною плазми, відомих як глобальні резонатори $[2,4]$. Виконання цієї програми здійснюється у тісній співпраці з вченими Свросоюзу та США.

Що стосується озонової діри, слід нагадати, що це явище було відкрито у 1985 р. саме за даними британських антарктичних станцій «Халлі» і «Фарадей». Після передачі станції «Фарадей» (нині - «Академік Вернадський) ці дослідження продовжують українські вчені. Визначено роль озонового шару в тропосферно-іоносферній взаємодії - він є своєрідним екраном такої взаємодії. Наразі зусилля вчених спрямовано на вивчення процесів у стратосфері та змін у динаміці озонового шару над Антарктикою і на побудову моделі, яка б дозволяла кількісно характеризувати передумови розвитку озонової діри та оцінювати їі динамічні параметри.

Не можу не відзначити досягнення в галузі біологічних досліджень. Вони різнопланові, охоплюють практично все біорізноманіття i пов'язані з вивченням як морських, так і наземних антарктичних екосистем. Одним 3 напрямів досліджень у полярних регіонах, який стрімко розвивається останнім часом, є біопроспектинг - вивчення специфічних пристосувань мікроорганізмів, рослин та тварин, які мешкають в екстремальних умовах, 3 метою застосування виявлених генетичних, біохімічних та фізіологічних механізмів при розро-
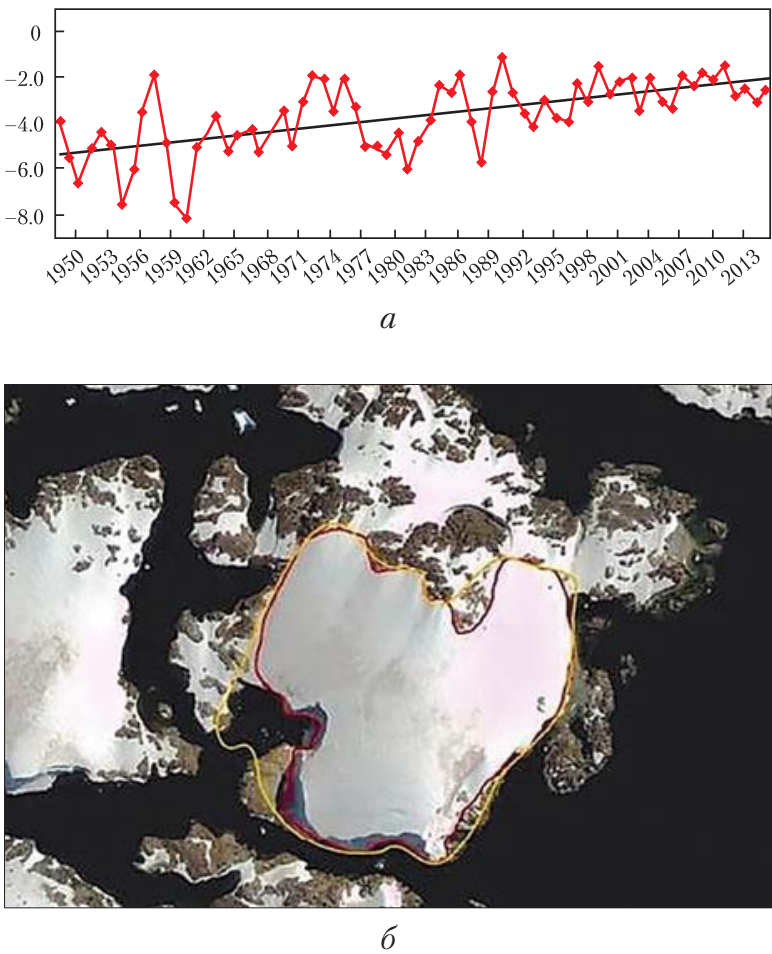

$\boldsymbol{P} \boldsymbol{u c}$. 5. Тренд середньорічної температури повітря на станції «Академік Вернадський» на фоні загальних тенденцій змін клімату в регіоні ( $a$ ). Контури льодового куполу о. Галіндез у 1956 р. (жовта лінія) і у 2014 р. (червона лінія) (б).

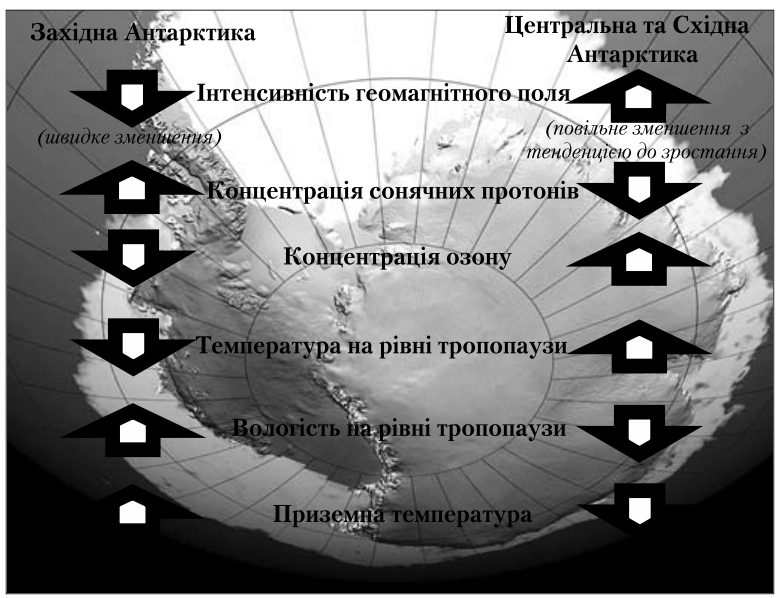

Puc. 6. Запропоновано механізм зв'язку вікових варіацій геомагнітного поля з процесами в нижній стратосфері, якій пояснює відмінності температурних змін на заході та у центрі й на сході Антарктиди [9] 
бленні промислових біотехнологій. Українські вчені успішно здійснюють пошук продуцентів біологічно активних речовин, створюють колекції та унікальний генофонд антарктичних організмів, активних в умовах низьких температур. Зараз цей напрям інтенсивно розвивається в Національному антарктичному науковому центрі.

Роботи з геолого-геофізичного та геокосмічного напрямів Програми забезпечили активну участь України в програмі Міжнародного полярного року 2007/2008. За цикл робіт «Структура і динаміка геофізичних полів як відображення еволюції та взаємодії геосфер в Антарктиці» авторський колектив, до складу якого входили 7 представників різних установ НАН України, у 2015 р. було удостоєно Державної премії України в галузі науки і техніки [2]. За результатами наукових досліджень i розробок опубліковано низку монографій та наукових статей у найпрестижніших зарубіжних виданнях з високим імпакт-фактором.

Тепер кілька слів про фінансування. На наукову і науково-технічну діяльність України в Антарктиці у 2021 р. заплановано 128,31 млн грн; у 2022 р. - 101,51; у 2023 р. - 101,51 млн грн. Обсяги фінансування Програми на сьогодні, порівняно з минулими роками, не такі вже й малі. Це дало змогу в останні два роки закупити нову високовартісну апаратуру, розпочати капітальну модернізацію інфраструктури станції та виділити достатні кошти на виконання наукових проєктів. Отже, за 25 років досліджень України в Антарктиці зусиллями багатьох наукових установ НАН України, закладів вищої освіти, організацій і відомств під загальним керівництвом Національного антарктичного наукового центру при $\mathrm{MOH}$ України було створено науково-методологічне підгрунтя і закладено матеріальну базу для проведення цілеспрямованих фундаментальних і прикладних досліджень льодового континенту.

Звісно, маємо і проблеми. За браком часу зупинюся лише на двох із них.

По-перше, це недостатньо ефективна координація співпраці Національного антарк- тичного наукового центру з установами НАН України при проведенні комплексних наукових досліджень, недостатній рівень поінформованості щодо програм та стратегії наукових досліджень, а також щодо складу і функціонування міжвідомчої Науково-технічної ради «Антарктика». Крім того, розподіл коштів на фінансування різних наукових напрямів є нерівномірним. Для вирішення цієї проблеми пропонується створити Міжвідомчу наукову раду з вивчення Антарктики при Президії НАН України з метою координації діяльності НАН України і МОН України в процесі визначення стратегії, основних наукових напрямів та під час виконання завдань Державної програми проведення досліджень в Антарктиці, а також ширшого залучення наукових установ Академії до виконання проєктів Програми.

Друга проблема стосується необхідності розширення присутності України в Антарктиці, що потребує використання спеціалізованого науково-дослідного судна. Без вирішення цього ключового питання формування стратегічних завдань за науковими напрямами, розширення району досліджень та територіальної присутності (заснування нових сезонних та перманентних станцій) не може бути реалізовано повною мірою.

Дякую за увагу!

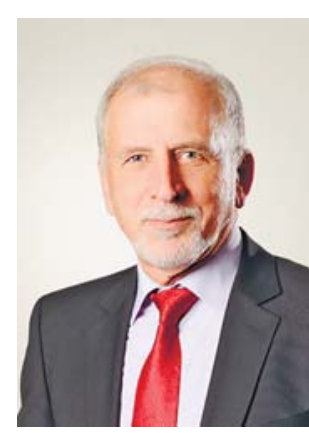
МАКСИМЧУК
Валентин Юхимович - член-кореспондент НАН України, директор Карпатського відділення Інституту геофізики ім. С.І. Субботіна НАН України

Шановний пане президенте!

Шановні члени Президії!

Дозвольте ознайомити Вас з головними результатами моніторингових геофізичних досліджень, які виконуються установами НАН України в Антарктиці з метою вивчення су-

ISSN 1027-3239. Visn. Nac. Acad. Nauk Ukr. 2021. (4) 
часних геодинамічних процесів у літосфері Антарктичного півострова, тектонічного районування та виявлення тектонічно активних геологічних структур. Як відомо, з активними розломами часто пов’язані родовища корисних копалин, у тому числі нафти і газу.

Тектономагнітні дослідження грунтуються на вивченні часових змін локального магнітного поля Землі - тектономагнітних аномалій, та проведенні їх тектонофізичної інтерпретації.

Район української антарктичної станції «Академік Вернадський» розташований у зоні впливу субдукційних процесів на границях Антарктичної плити та плити Скоша, рифту Брансфілд. Поблизу станції проходять глибинні розломи субширотного та субмеридіального простягання, в межах яких відбуваються активні сейсмотектонічні процеси. Їх вивчення має велике значення для побудови моделей глибинної будови земної кори та прогнозування родовищ корисних копалин.

Для проведення тектономагнітних досліджень у 1998 р. поблизу станції «Академік Вернадський» фахівцями Карпатського відділення Інституту геофізики ім. C.I. Субботіна НАН України було створено тектономагнітний полігон [10]. 3 огляду на специфіку району проведення робіт пункти полігону закладалися переважно на островах архіпелагу Аргентинські острови. Сьогодні їх мережа налічує 33 пункти, на яких з інтервалом 1-2 роки вже виконано 13 циклів спостережень (рис. 7).

За результатами проведених спостережень досліджено динаміку локального магнітного поля в районі станції та його просторово-часові особливості. За інтенсивністю і характером часових змін магнітного поля було виявлено геодинамічно активні зони - тектонічний розлом Пенола і тектонічне порушення в околі острова Троє Маленьких Поросят (рис. 8) $[11,12]$.

3 урахуванням п’єзомагнітного механізму тектономагнітних аномалій проведено оцінку величини та напрямку тектонічних напружень у верхній частині земної кори. Зроблено висновок, що в районі архіпелагу гірські породи зазнають розтягальних горизонтальних напру-
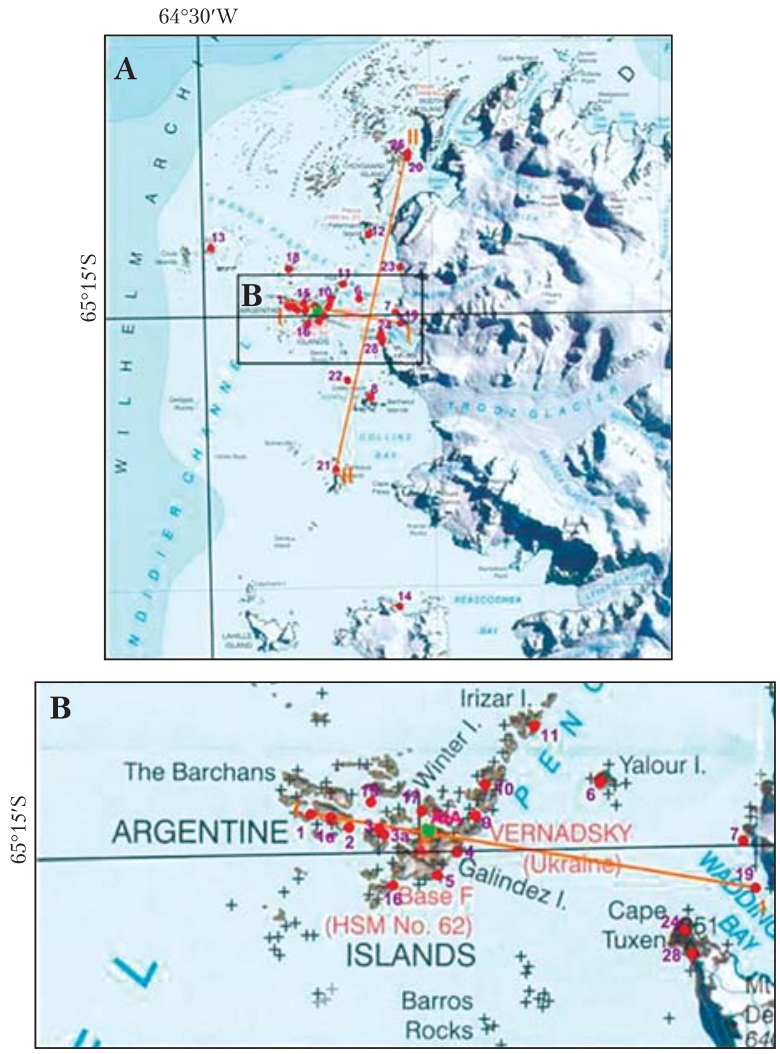

Puc. 7. Розташування пунктів тектономагнітного полігону

жень у східній частині полігону і стискних - у західній (кілька бар/рік), що підтверджується результатами геодезичних спостережень за кінематикою блоків земної кори [2].

Магнітоваріаційні спостереження, які здійснюють фахівці Інституту геофізики ім. С.I. Субботіна НАН України та Карпатського відділення ІГФ ім. С.І. Субботіна НАН України, спрямовані на вивчення геоелектричного розрізу земної кори і верхньої мантії (магнітоваріаційні зондування) та сучасної динаміки земної кори (магнітоваріаційний моніторинг).

За даними магнітоваріаційного зондування вперше для Антарктиди було побудовано моделі геоелектричного розрізу до глибини 1200 км, а також досліджено просторовий розподіл векторів індукції (вектор Візе), що дозволило оцінити латеральний розподіл електропровідності літосфери та обгрунтувати гіпотезу щодо наявності великої аномалії елек- 


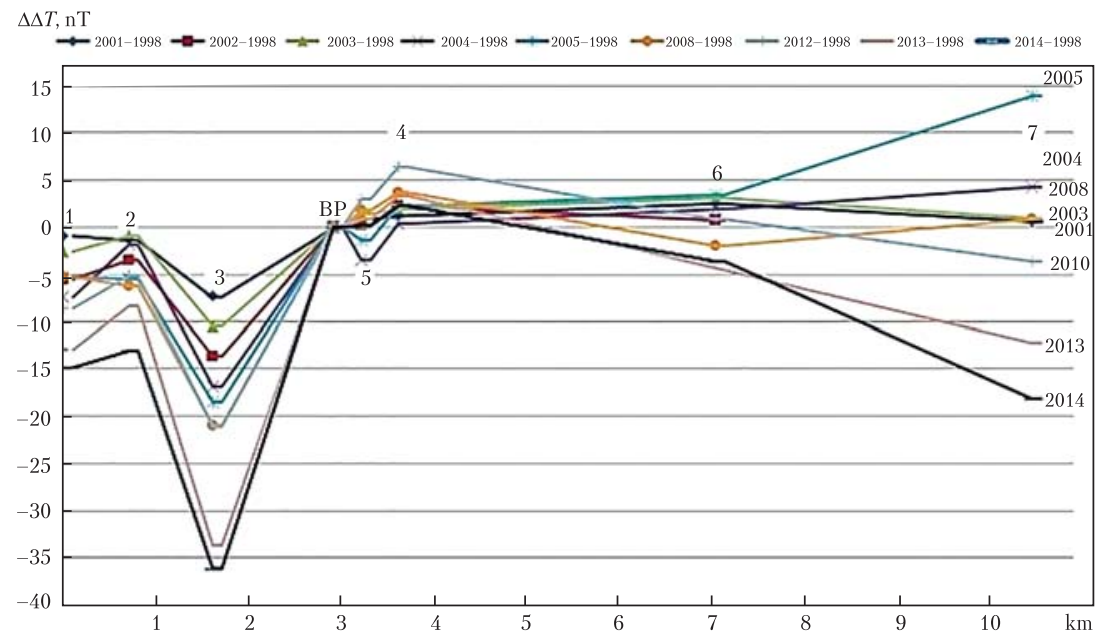

Puc. 8. Часові зміни геомагнітного поля $\Delta \mathrm{F}$ (аномалії $\Delta \Delta \mathrm{F}$ ) вздовж профіля I-I БарханиРасмуссен за різні часові періоди; 1-7 - пункти спостережень тропровідності в зоні колізії плити Скоша та Антарктичної плити.

Магнітоваріаційний моніторинг здійснюється на станції «Академік Вернадський» уже протягом 25 років. При цьому вивчаються зміни в часі компонент вектора електричної індукції для геомагнітних варіацій у діапазоні від 5 до 60 хв, які несуть у собі інформацію про електричну провідність гірських порід на різних глибинах.

За результатами багаторічних магнітоваріаційних спостережень на станції було виявлено аномальні зміни компонент вектора індукції перед сильними землетрусами (з магнітудою понад 8) у районі зон субдукції плит Скоша, Антарктичної та Південно-Американської плит. Це відкриває можливості для моніторингу сейсмотектонічних процесів та виявлення провісників сильних землетрусів у сейсмоактивних зонах, у зонах субдукції плити Скоша та Антарктичної плити (рифту Брансфілд) (рис. 9) [13].

За даними GPS-спостережень науковцями Інституту геодезії Національного університету «Львівська політехніка» досліджено кінематику Антарктичної тектонічної плити.

Для вивчення деформаційних процесів земної кори Антарктичного півострова було використано значення векторів швидкостей горизонтальних рухів пунктів, отриманих з GPSкампаній протягом 1995-1998 рр. Значення швидкостей горизонтальних зміщень пунктів перебувають у межах від +15,6 до +29,8 мм/рік та характеризуються переважно північним спрямуванням. Максимальну швидкість руху зафіксовано для пункту VERN, розташованого в районі української антарктичної станції «Академік Вернадський», спостереження на якому виконували в 1995, 2003 і 2005 pp. [2].

Для вивчення зміщень блоків земної кори у районі станції було створено геодинамічний полігон, на якому встановлено прецизійну геодезичну мережу та проведено повторні GPS-спостереження. Це дозволило визначити відносні швидкості і напрямки руху окремих ділянок геодинамічного полігону, які коливаються в межах 10-17 мм/рік, та запропонувати модель їх тектонічної інтерпретації (рис. 10) [2].

Зусиллями фахівців Інституту геофізики ім. C.I. Субботіна НАН України виконано значний обсяг морських геомагнітних спостережень архіпелагу Аргентинські острови та створено унікальну за точністю і детальністю карту аномального магнітного поля. Таким чином вперше було отримано інформацію про детальну структуру аномального магнітного поля району робіт і побудовано магнітні 3D-моделі, оцінено глибину залягання та просторовий розподіл геологічних об'єктів - джерел цих аномалій. Встановлено, що їх глибини залягання коливаються в межах від 0 до 200 м [2].

ISSN 1027-3239. Visn. Nac. Acad. Nauk Ukr. 2021. (4) 


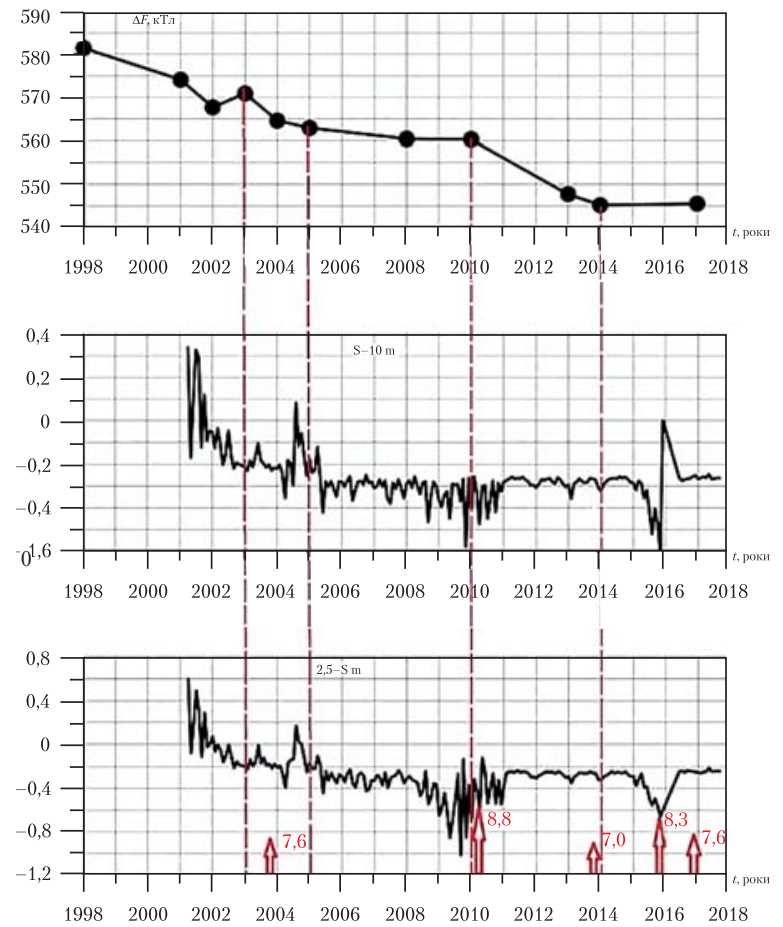

Puc. 9. Часові зміни локального магнітного поля на п. 3 Антарктичного тектономагнітного полігону та компоненти А векторів індукції на магнітній обсерваторії «Аргентинські острови» (AIA)

Зазначену карту було доповнено результатами вивчення аномального магнітного поля островів архіпелагу, отриманими фахівцями Карпатського відділення Інституту геофізики ім. С.І. Субботіна НАН України

Виділені локальні аномалії на островах та їх акваторіях є першочерговими об’єктами для подальшого вивчення геологічної будови та прогнозування покладів рудних корисних копалин.

Отже, комплексний підхід, який об'єднав фахівців з геології, геофізики, геодезіі, радіофізики, електромагнетизму та приладобудування, дає змогу на унікальному природному полігоні української антарктичної станції «Академік Вернадський» досліджувати широке коло проблем у різних галузях природничих наук.

Найважливіші результати геофізичних досліджень, які установи НАН України виконують у рамках Державної цільової науковотехнічної програми проведення досліджень ISSN 1027-3239. Вісн. НАН України, 2021, № 4

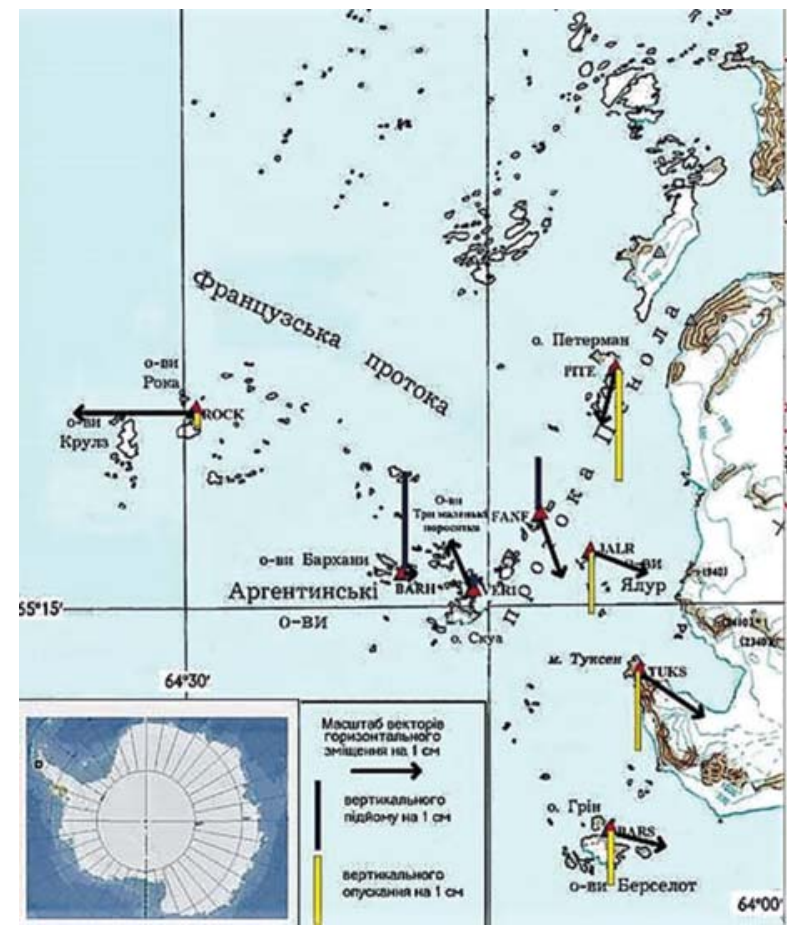

Puc. 10. Схема кінематики пунктів геодезичної мережі [2]

в Антарктиці, можна згрупувати в три такі категорії:

1. Створено основу (полігони, методики, апаратурні комплекси, технології, теоретичні моделі, бази даних моніторингових спостережень) для дослідження взаємодії різних геосфер за даними про просторово-часову структуру геофізичних полів. Запропоновано і впроваджено нові підходи та методи обробки даних дистанційних зондувань, тектономагнітних та магнітоваріаційних спостережень, моніторингу динаміки льодовикового покриву, електромагнітного зондування тощо.

2. Отримано низку нових фундаментальних результатів щодо динаміки геофізичних полів та взаємодії геосфер в Антарктиці. 3окрема, створено моделі геодинамічної еволюції та глибинної будови літосфери, процесів у геокосмосі, зв'язку атмосферної та космічної погодних систем, довгострокових змін навколишнього середовища, отримано важливі дані про ресурсний потенціал регі- 
ону. Це дозволило закласти науково-методологічну основу і матеріальну базу для розширення кола цілеспрямованих фундаментальних і прикладних досліджень, зокрема для виконання практичних завдань, пов'язаних з політико-економічними перспективами використання Україною морського простору і ресурсів Антарктики.

3. Роботи за геолого-геофізичним та геокосмічним напрямами Державної програми досліджень в Антарктиці забезпечили активну участь України в програмі Міжнародного полярного року 2007/2008. Про важливість отриманих результатів свідчить той факт, що у 2015 р. цикл наукових праць «Структура і динаміка геофізичних полів як відображення еволюції та взаємодії геосфер в Антарктиці» було відзначено Державною премією України в галузі науки і техніки.

Дякую за увагу!

\section{REFERENCES}

[СПИСОК ЛІТЕРАТУРИ]

1. Komisarenko S. My Antarctics. Kyiv: LAT\&K, 2020.

[Комісаренко С. Моя Антарктика. Київ: ЛАТ\&К, 2020.]

2. Bakhmutov V.H., Tretyak K.R., Maksymchuk V.Yu., Hlotov V.M., Hreku R.Kh., Yehorova T.P., Zalizovskyi A.V., Koloskov O.V., Korchahin I.M., Pronenko V.O. Structure and dynamics of geophysical fields in West Antarctica (Struktura i dynamika heofizychnykh poliv u Zakhidniy Antarktytsi). Lviv, 2017. (in Ukrainian).

[Бахмутов В.Г., Третяк К.Р., Максимчук В.Ю., Глотов В.М., Греку Р.Х., Єгорова Т.П., Залізовський А.В., Колосков О.В., Корчагін І.М., Проненко В.О. Структура і динаміка геофізичних полів у Західній Антарктиці. Львів: Львівська політехніка, 2017.]

3. Marchenko O.M., Tretyak K.R. (eds) Study of the gravitational field, ocean topography and crustal motions in the Antarctic region (Doslidzhennya hravitatsiynoho polya, topohrafiyi okeanu ta rukhiv zemnoyi kory v rehioni Antarktyky). Lviv, 2012 (in Ukrainian).

[Марченко О.М., Третяк К.Р., Кульчицький А.Я., Голубінка Ю.І., Марченко Д.О., Третяк Н.П. Дослідження гравітаційного поля, топографії океану та рухів земної кори в регіоні Антарктики. За заг. ред. О.М. Марченка, К.Р. Третяка. Львів: Вид-во Львівської політехніки, 2012.]

4. Litvinenko L.N., Yampolski Yu.M. (eds) Electromagnetic manifestations of geophysical effects in Antarctica (Elektromagnitnyye proyavleniya geofizicheskikh effektov v Antarktide). Kharkov, 2005 (in Russian).

[Электромагнитные проявления геофизических эффектов в Антарктиде. Под ред. Л.Н. Литвиненко, Ю.М. Ямпольского. Харьков, 2005.]

5. Larter R.D., Barker P.F. Effects of ridge crest-trench interaction on Antarctic-Phoenix spreading: forces on a young subducting plate. Journal of Geophysical Research. 1991. 96(B12): 19583-19607. DOI: https://doi. org/10.1029/91JB02053

6. Golynsky A.M., Chiappini M., Damaske D., Ferraccioli F., Ferris J.K., Finn C., Ghigella M., Ishihara T., Jonson A.C., Kim H.R., Kovasc L., LaBresque J., Masolov V., Nogi Y., Purucker M., Taylor P., Torta M. ADMAP - Magnetic anomaly map of the Antarctic. 1:10 000000 scale map. BAS (Misc) 10. 2001.

7. Yegorova T., Bakhmutov V. Crustal structure of the Antarctic Peninsula sector of the Gondwana margin around Anvers Island from geophysical data. Tectonophysics. 2013. 585: 77-89. DOI: https://doi.org/10.1016/j.tecto.2012.09.029

8. Greku R.Kh., Gozhik P.F., Litvinov V.A., Usenko V.P., Greku T.R. Atlas of the Antarctic deep structure with the Gravimetric Tomography. Kyiv, 2009.

9. Kilifarska N.A., Bakhmutov V.G., Melnyk G.V. The hidden link between Earth's magnetic field and climate. Elsevier, 2020. DOI: https://doi.org/10.1016/C2018-0-01667-9

10. Maksymchuk V.Yu., Horodyskyy Yu.M., Chobotok I.O., Bakhmutov V.H., Kuznietsova V.H. Tectonomagnetic investigations in the Western Antarctic. Geodynamics. 2004. (1): 40-45. (in Ukrainian).

[Максимчук В., Городиський Ю., Чоботок І., Бахмутов В., Кузнєцова В. Тектономагнітні дослідження в західній Антарктиці. Геодинаміка. 2004. № 1. С. 40-45.]

11. Maksymchuk V.Yu., Bakhmutov V.G., Gorodyskiy Yu.M., Chobotok I.A. State, results and prospects of tectonomagnetic research in West Antarctica. Geophysical journal. 2008. 30(1): 71-83 (in Russian). 
[Максимчук В.Ю., Бахмутов В.Г., Городыский Ю.М., Чоботок И.А. Состояние, результаты и перспективы тектономагнитных исследований в Западной Антарктике. Геофиз. журнал. 2008. Т. 30, № 1. С. 71-83.]

12. Maksymchuk V.U., Bakhmutov V.G., Horodyskyy Yu.M., Chobotok I.O. Results and perspectives of tectonomagnetic investigations in the Western Antarctic. Annals of Geophysics. 2009. 52(1): 35-43. DOI: https://doi.org/10.4401/ ag-4571

13. Maksymchuk V.Yu., Chobotok I.O., Klymkovych T.A., Kuderavets R.S., Nakalov E.F., Otruba Y.S. Complex Magnetovariational and Tectonomagnetic Monitoring of Recent Geodynamics in the Western Slope of the Antarctic Peninsula. Ukrainian Antarctic Journal. 2018. (1): 3-19. DOI: https://doi.org/10.33275/1727-7485.1(17).2018.27 [Максимчук В.Ю., Чоботок І.О., Климкович Т.А., Кудеравець Р.С., Накалов Є.Ф., Отруба Ю.С. Комплексний тектономагнітний та магнітоваріаційний моніторинг сучасної геодинаміки земної кори західного схилу Антарктичного півострова. Украӥнський антарктичний журнал. 2018. № 1. С. 3-19.]

\section{Vladimir G. Bakhmutov}

ORCID: https://orcid.org/0000-0003-3804-9953

Subbotin Institute of Geophysics of the National Academy of Sciences of Ukraine, Kyiv, Ukraine

\section{ON THE RESULTS OF SCIENTIFIC RESEARCH OF UKRAINIAN SCIENTISTS IN ANTARCTICA}

Transcript of scientific report at the meeting of the Presidium of the NAS of Ukraine,

March, 17, 2021

The report is devoted to the $25^{\text {th }}$ anniversary of the founding of the Vernadsky Research Base. The history of development of Antarctic research in Ukraine is considered. It is emphasized that the specialists of the National Academy of Sciences of Ukraine have played and continue to play a leading role in the initiation and implementation of various scientific studies at the Vernadsky Research Base. The most significant results obtained by scientists of the institutions of the NAS of Ukraine in the framework of their participation in the implementation of the State Targeted Scientific and Technical Program for Research in Antarctica for 2011-2023 are presented.

Keywords: Antarctic research, monitoring observations, Vernadsky Research Base, Galindez Island. 